\title{
ZAKRES OBOWIĄZYWANIA ZASADY NEMO SE IPSUM ACCUSARE TENETUR NA TLE NOWYCH ROZWIĄZAŃ TECHNICZNYCH I PRAWNYCH W MOTORYZACJI
}

Dnia 29 kwietnia 2015 r. Parlament Europejski i Rada Unii Europejskiej przyjęły rozporządzenie nr 2015/758 w sprawie wymagań dotyczących homologacji typu na potrzeby wdrożenia systemu pokładowego eCall opartego na numerze alarmowym 112 oraz zmiany dyrektywy 2007/46/WE ${ }^{1}$. Zgodnie z nim od 31 marca 2018 r. nowe samochody muszą być wyposażane w automatyczny system $e$ Call, aby zostać dopuszczone do ruchu w państwach członkowskich UE. System ten w przypadku poważnej kolizji lub wypadku samoczynnie nawiązuje łączność ze służbami ratunkowymi, podając pozycję auta (dokładne dane określające długość i szerokość geograficzną miejsca zdarzenia), sposób ułożenia pojazdu przy jego ewentualnym przewróceniu się, liczbę odpalonych „poduszek”, których uruchomienie inicjuje działanie całego systemu oraz liczbę zajętych miejsc siedzących, a umiejscowienie czujników w siedzeniach i pasach umożliwia nawet rozpoznanie fotelika dziecięcego ${ }^{2}$. W preambule przywołanego rozporządzenia wyraźnie sformułowano oczekiwanie, że

\footnotetext{
* Uniwersytet Jagielloński; e-mail: geigerek@gmail.com, https://orcid.org/ 0000-0002-9600-2064.

1 Dz.Urz. UE L 123/77, nr CELEX 32015R0758. Z uwagi na „swoistość” oficjalnego tłumaczenia na język polski, warto przytoczyć, że w wersji w języku angielskim rozporządzenie to dotyczy: „type-approval requirements for the deployment of the eCall in-vehicle system based on the 112 service and amending Directive 2007/46/EC", a więc po prostu wymagań homologacyjnych.

2 Rozmowa z Maciejem Pertyńskim, dziennikarzem motoryzacyjnym, https://www. wirtualnemedia.pl/artykul/sportowy-mercedes-zawiadomil-policje-w-elblagu-o-tym-ze-uczestniczyl-w-wypadku-to-normalne-dzialanie-systemu-e-call-dlaczego-jak-korzystac [dostęp: 19.11.2019 r.].
} 
unijny system eCall ograniczy liczbę ofiar śmiertelnych i stopień obrażeń odnoszonych w wypadkach w ruchu drogowym w Unii dzięki wczesnemu alarmowaniu służb ratowniczych. Obowiązkowe wprowadzenie systemu pokładowego eCall [...] przyczyniłoby się do zmniejszenia liczby ofiar śmiertelnych i osób ciężko rannych, do ograniczenia wydatków na opiekę zdrowotną, a także do zmniejszenia utrudnień w ruchu spowodowanych przez wypadki oraz innych kosztów ${ }^{3}$.

Dnia 6 sierpnia 2019 r. w Elblągu kierowca sportowego mercedesa wjechał z dużą prędkością na parking podziemny w centrum handlowym. Rozpędzony samochód uderzył w inny zaparkowany tam pojazd, a następnie $\mathrm{w}$ filar parkingu. $\mathrm{W}$ mercedesie znajdowały się cztery osoby, jednak żadnej z nich nic się nie stało. Siła uderzenia była jednak na tyle duża, że w samochodzie urwało się koło i wystrzeliły poduszki powietrzne. $W$ niedługim czasie na miejsce zdarzenia przybyli policjanci, którzy stwierdzili, że w organizmie kierowcy znajdują się środki odurzające. W toku dalszych czynności została mu pobrana krew, którą zabezpieczono na potrzeby dalszych badań. W tym stanie faktycznym kierujący mercedesem mógł narazić się na odpowiedzialność karną z art. 178a § 1 Kodeksu karnego ${ }^{4}$, a decydujące znaczenie miało tu ustalenie, czy stężenie środków odurzających było wystarczające do stwierdzenia, że znajdował się on pod ich wpływem. Co istotne, policjanci zostali wezwani na miejsce zdarzenia przez operatora numeru alarmowego 112, automatycznie powiadomionego o kolizji za pośrednictwem zamontowanego w mercedesie systemu eCall, a nie na skutek zgłoszenia kolizji przez kogokolwiek.

Artykuł 74 § 1 K.p.k. stanowi normatywne wyrażenie zasady nemo se ipsum accusare tenetur rozumianej jako prawo do nieobciążania się. Nie była ona znana prawu rzymskiemu. Jej najwcześniejszych śladów można się doszukać w prawie talmudycznym, które zabraniało dopuszczania jako dowodu przed sądem jakiegokolwiek przyznania się do winy, nawet dobrowolnego. W XIII w. św. Tomasz z Akwinu, powołując się na św. Jana Chryzostoma, wyraził pogląd, że nikt nie jest zobowiązany dobrowolnie donosić o przestępstwie, które popełnił. Dopiero w latach 40. XVII w. w Anglii oskarżonego zwolniono z obowiązku składania

\footnotetext{
3 Punkt (7) preambuły przywołanego rozporządzenia.

4 „Kto, znajdując się w stanie nietrzeźwości lub pod wpływem środka odurzającego, prowadzi pojazd mechaniczny w ruchu lądowym, wodnym lub powietrznym, podlega grzywnie, karze ograniczenia wolności albo pozbawienia wolności do lat 2".
} 
zeznań pod przysięgą. Po raz pierwszy prawo do nieobciążania się zostało wprost wyrażone $\mathrm{w}$ akcie prawnym dopiero 15 grudnia 1791 r., kiedy weszła w życie piąta poprawka do Konstytucji Stanów Zjednoczonych, zgodnie z którą "nikt nie może być zmuszony do zeznawania w sprawie karnej na swoją niekorzyść" 5 . W polskich procedurach karnych prawo do nieobciążania zostało wprost wyrażone dopiero w Kodeksie postępowania karnego z dnia 6 czerwca 1997 r. ${ }^{6}$, przy czym już w kodyfikacji z dnia 19 kwietnia 1969 r. wprowadzono katalog czynności dowodowych, którym oskarżony obowiązany był się poddać7. „Zważyć jednak należy, że popełnienie przestępstwa przez obywatela stanowi tak ciężkie naruszenie porządku prawnego i tak dotkliwie krzywdzi poszkodowaną jednostkę, że pewien rygoryzm postępowania karnego musi być usprawiedliwiony" ${ }^{8}$. Odzwierciedleniem tego przekonania jest odmówienie zasadzie nemo se ipsum accusare tenetur charakteru normy definitywnie wiążącej, bez jakichkolwiek od niej wyjątków. Przywołany art. 74 K.p.k. dość wyraźnie precyzuje granice braku obowiązku dostarczania przez oskarżonego albo podejrzanego dowodów przeciwko samemu sobie. W § 2 tego przepisu wskazano, że osoba ta jest zobowiązana do poddania się czynnościom oględzin ciała, pobrania odcisków palców, wymazu ze śluzówki policzków, krwi, włosów lub wydzielin z organizmu, fotografowania, okazania innym osobom, a wreszcie badaniom lekarskim, w tym psychiatrycznym oraz psychologicznym. $Z$ art. $74 \S 3$ K.p.k. wynika natomiast, że te same

5 A. Lach, Granice badań oskarżonego w celach dowodowych. Studium w świetle reguty nemo se ipsum accusare tenetur i prawa do prywatności, Torun 2010, s. 49-52.

${ }^{6} \quad$ Art. 74 § 1 K.p.k.: „Oskarżony nie ma obowiązku dowodzenia swej niewinności ani obowiązku dostarczania dowodów na swoją niekorzyść".

7 Art. 65 K.p.k. z 1969 r.: „Jeżeli jest to potrzebne dla celów dowodowych, oskarżony jest obowiązany poddać się: 1) oględzinom zewnętrznym ciała oraz innym badaniom nie połączonym z naruszeniem integralności ciała; w szczególności wolno od oskarżonego pobrać odciski, fotografować go oraz okazać go w celach rozpoznawczych innym osobom w odpowiednio odtworzonych warunkach; okazanie można przeprowadzić również tak, aby wyłączyć możliwość rozpoznania osoby przesłuchiwanej przez osobę rozpoznawaną, 2) badaniom psychologicznym i psychiatrycznym oraz badaniom połączonym z dokonaniem zabiegów na jego ciele - z wyjątkiem chirurgicznych - pod warunkiem że dokonywane są przez uprawnionego do tego pracownika służby zdrowia z zachowaniem wskazań wiedzy lekarskiej i nie zagrażają zdrowiu oskarżonego; w szczególności oskarżony jest obowiązany przy zachowaniu tych warunków poddać się pobraniu krwi lub wydzielin organizmu".

8 J. Haber, Pojęcie i istota przestanek procesu karnego, Państwo i Prawo 1967, z. 2, s. 208. 
obowiązki ciążą na osobie podejrzanej, z wyjątkiem poddania się badaniom lekarskim i psychologicznym. Należy zauważyć, że w początkowym okresie obowiązywania K.p.k. korzystniej kształtował pod tym względem pozycję procesową osoby podejrzanej. Dopiero od 1 lipca 2003 r. ${ }^{9}$ dopuszczalne stało się pobranie od niej krwi, włosów lub wydzielin organizmu bez jej zgody, a od 1 lutego 2005 r. ${ }^{10}$ zezwolono na pobranie wymazu ze śluzówki policzka. Nowelizacje te świadczyły o zamiarze ustawodawcy, by osoba podejrzana, będąca potencjalnym oskarżonym, jako źródło dowodowe ułatwiała poznanie prawdy materialnej ${ }^{11}$.

Jakkolwiek art. 74 § 1 K.p.k. wprost dotyczy oskarżonego, a w związku z odesłaniem ustanowionym $\mathrm{w}$ art. 71 § 3 K.p.k. także podejrzanego, to nie ulega wątpliwości, że normuje on także sytuację osoby podejrzanej, mimo że formalnie nie przedstawiono jej zarzutów. Stanowisko to jest ugruntowane w orzecznictwie Sądu Najwyższego ${ }^{12}$. Należy również zauważyć, że norma wyrażona w art. 74 § 3 K.p.k., obejmująca zakresem swej hipotezy osobę podejrzaną, stanowi w istocie wyjątek od regulacji wynikającej z $\S 1$ tego przepisu. W związku z tym powinien on dotyczyć również osoby podejrzanej, w przeciwnym wypadku bowiem należałoby

9 Na podstawie art. 1 pkt 21 ustawy z dnia 10 stycznia 2003 r. o zmianie ustawy - Kodeks postępowania karnego, ustawy - Przepisy wprowadzające Kodeks postępowania karnego, ustawy o świadku koronnym oraz ustawy o ochronie informacji niejawnych (Dz. U. z 2003 r. Nr 7, poz. 155).

10 Na podstawie art. 2 pkt 1 ustawy z dnia 17 grudnia 2004 r. o zmianie ustawy o Policji oraz ustawy - Kodeks postępowania karnego (Dz. U. z 2005 r. Nr. 1, poz. 10). Art. 74 K.p.k. został jeszcze znowelizowany dnia 9 listopada 2013 r., na podstawie art. 1 pkt. 19 ustawy z dnia 27 września 2013 r. o zmianie ustawy - Kodeks postępowania karnego oraz niektórych innych ustaw (Dz. U. z 2013 r. poz. 1247), kiedy to dodano do niego § 3a dopuszczający stosowanie zatrzymania i przymusowego doprowadzenia oskarżonego lub osoby podejrzanej, a także stosowanie wobec nich siły fizycznej lub środków technicznych służących obezwładnieniu, w zakresie niezbędnym do dokonania danej czynności. Nowelizacja ta nie stanowiła jednak nowości normatywnej, a jedynie podnosiła do rangi ustawowej istniejące już regulacje, zawarte uprzednio w rozporządzeniu.

11 P. Mazur, Zmiana sytuacji procesowej osoby podejrzanej i oskarżonego a zasada prawdy materialnej po nowelizacji kodeksu karnego z dnia 10 stycznia 2003 r. (wybrane zagadnienia), w: Zasada prawdy materialnej, red. Z. Sobolewski, G. Artymiak, Zakamycze 2006, s. 157.

12 Przykładowo w wyroku SN z dnia 9 lutego 2004 r., V KK 194/03, wskazano, że „Nie ulega zatem wątpliwości, że od chwili zatrzymania Krzysztof F. korzystał ze swobody wypowiedzi co do czynu, z którym wiązała się ta czynność Policji. Podobnie jak podejrzany, nie miał on obowiązku dostarczenia dowodów na swoją niekorzyść (art. 74 $\S 1$ in fine - nemo se ipsum accusare tenetur)". 
uznać cały ten przepis za wadliwie skonstruowany. Wyrażona w art. 74 $\S 1$ K.p.k. zasada nemo se ipsum accusare tenetur, zakresem której objęty jest również brak obowiązku autodenuncjacji, czyli zawiadomienia o popełnionym przez siebie przestępstwie, obejmuje swym zasięgiem wszelkie zachowania oskarżonego oraz wszelkie dowody. Jak wskazano, nie ma ona charakteru absolutnego, jednak żadne badania i czynności procesowe nie mogą zakładać aktywnego współdziałania oskarżonego ${ }^{13}$.

W fundamentalnym dla europejskiego porządku praw człowieka akcie prawnym - Europejskiej konwencji praw człowieka - zasada nemo se ipsum accusare tenetur również nie została wprost wyrażona. Nie budzi jednak wątpliwości, że jest ona elementem prawa do sprawiedliwego rozpatrzenia sprawy, wyrażonego w art. 6 ust. $1 \mathrm{EKPCz}$, a niesformułowanie jej w sposób bezpośredni wynikało z przekonania o niekwestionowanym związku tej zasady z koncepcją sprawiedliwego procesu oraz chęci uniknięcia nadmiernej rozwlekłości przepisu ${ }^{14}$. Wprost wyraził to Europejski Trybunał Praw Człowieka w orzeczeniu Allan v. The United Kingdom, stwierdzając, że ,jeśli chodzi o przywilej przeciwko samooskarżeniu lub prawo do milczenia, Trybunał powtarza, że są to powszechnie uznane międzynarodowe standardy, które są sercem sprawiedliwego procesu"15. Istnieją również poglądy, zgodnie z którymi zasada nemo se ipsum accusare tenetur wynika z ust. 2 przywołanego artykułu konwencji, konsekwencją domniemania niewinności bowiem jest prawo do nieujawniana dowodów własnej winy, lub z ust. 3, w którym wskazano minimalny katalog środków pozostających $\mathrm{w}$ dyspozycji oskarżonego ${ }^{16}$.

Problem postawiony $\mathrm{w}$ tym opracowaniu sprowadza się do pytania, czy dane przesłane przez system informatyczny samochodu o zdarzeniu drogowym, będącym następstwem przestępstwa spowodowanego przez właściciela tego pojazdu, mogą być podstawą podjęcia czynności

13 P. Sowiński, Prawo oskarżonego do milczenia oraz reguła nemo se ipsum accusare tenetur na tle dążenia organów procesowych do poznania prawdy materialnej w procesie karnym, w: Zasada prawdy materialnej..., s. 177-178. Przykładem jest niemożność przymuszenia oskarżonego do oddania próbki głosu.

14 B. Gronowska, Wyrok Europejskiego Trybunatu Praw Człowieka z dnia 5 listopada 2002 r. w sprawie Allan przeciwko Zjednoczonemu Królestwu (dot. prawa oskarżonego do milczenia a wydobycia przyznania się do winy podstępem), Prokuratura i Prawo 2003, nr 6, s. 151.

15 Wyrok ETPCz z dnia 5 listopada 2002 r., nr 48539/9, Allan przeciwko Zjednoczonemu Królestwu, zob. także przywołane tam orzeczenia.

16 P. Sowiński, Prawo oskarżonego..., s. 171-172. 
nakierowanych na prowadzenie postępowania karnego przeciwko tej osobie. Prima facie w grę mogą wchodzić trzy opcje. Pierwsza - tego rodzaju informacje nie są objęte zakresem zasady nemo se ipsum accusare tenetur, w związku z czym nie ma przeciwwskazań wobec ich procesowego wykorzystania. Druga, wprost przeciwna, skutkująca niemożliwością skorzystania $\mathrm{z}$ tych informacji. Wreszcie ostatnia, zgodnie z którą dane takie byłyby objęte omawianym zakazem, jednak ich wykorzystanie byłoby dopuszczalne na podstawie któregoś z wyjątków. De lege lata ostatnie z rozwiązań należy odrzucić, prawo do nieobciążania stanowi bowiem regułę, a nałożone na oskarżonego obowiązki są wyjątkami od niej. Zgodnie z dyrektywą interpretacyjną exceptiones non sunt extendendae dopuszczalność takiego dowodu, w przypadku objęcia go zakresem normy nemo se ipsum accusare tenetur, wymagałby ustawowej regulacji. Pozostaje więc wybór między dwiema pierwszymi opcjami, jednak aby go dokonać i należycie uzasadnić, konieczna jest dalsza analiza obowiązującego stanu prawnego i leżących u jego podstaw wartości.

Funkcjonowanie systemu eCall jest ściśle powiązane z systemem powiadamiania ratunkowego opartego na numerze alarmowym 112. Obsługiwany jest on przez centra powiadamiania ratunkowego tworzące jednolity system do obsługi zgłoszeń alarmowych, kierowanych do numerów alarmowych 112, 997, 998 i 999, umożliwiający przekazanie zgłoszenia alarmowego w celu zaangażowania właściwych zasobów ratowniczych ${ }^{17}$. To zatrudnieni $\mathrm{w}$ centrum powiadomienia ratunkowego operatorzy numeru alarmowego decydują, do której ze służb kierowane są zgromadzone dane o zgłoszeniu alarmowym ${ }^{18}$. Ogólne procedury obsługi tych zgłoszeń oraz sposób opracowywania i aktualizacji szczegółowych procedur zostały opisane w Rozporządzeniu Ministra Administracji i Cyfryzacji z dnia 28 kwietnia 2014 r. w sprawie organizacji i funkcjonowania centrów powiadamiania ratunkowego (Dz. U. z 2014 r. poz. 574). Zgodnie z $§ 14$ pkt. 3 tego rozporządzenia obsługa zgłoszeń alarmowych innych niż głosowe, przychodzących na numery obsługiwane w ramach systemu powiadamiania ratunkowego, odbywa się według następującej ogólnej procedury, której elementem jest przekazanie zgłoszenia alarmowego

17 Numer alarmowy 112. Struktura, https:/ / www.gov.pl/web/numer-alarmowy-112/ struktura [dostęp: 27.11.2019 r.].

18 Art. 8 ust. 1 pkt 1) lit. c) ustawy z dnia 22 listopada 2013 r. o systemie powiadamiania ratunkowego (tekst jednolity: Dz. U. z 2019 r. poz. 1077) 
właściwemu dyspozytorowi. Zgłoszenia przekazywane w ramach systemu eCall należą właśnie do kategorii „zgłoszeń innych niż głosowe”. Po jego otrzymaniu centrum powiadomienia ratunkowego powinno przekazać zgłoszenie do właściwego dyspozytora, czyli do instytucji powołanej do udzielania pomocy przy zdarzeniach danego rodzaju, np. pogotowia ratunkowego, policji, straży pożarnej. Obowiązek podjęcia decyzji, do kogo przekazać zgłoszenie, ciąży więc na obsługującym konkretne zgłoszenie operatorze numeru alarmowego. Nie znaczy to jednak, że od niego $\mathrm{w}$ pełni zależy proces decydowania. Zgodnie z $§ 10$ rozporządzenia szczegółowy katalog zdarzeń i odpowiednich do nich pytań, które należy zadać zgłaszającemu zgłoszenie alarmowe, szczegółowe procedury obsługi zgłoszeń alarmowych, a także procedury przekazania zgłoszenia w sytuacji awaryjnej są opracowywane i aktualizowane przez ministra właściwego do spraw administracji publicznej we współpracy z wojewodami, Policją, Państwową Strażą Pożarną i podmiotami ratowniczymi, a następnie są one zamieszczane $\mathrm{w}$ systemie teleinformatycznym centrów powiadamiania ratunkowego. Wynika stąd, że procedura postępowania ze zgłoszeniem z systemu eCall, a w szczególności sposób decydowania o tym, do jakiej instytucji przekazać informację o zdarzeniu drogowym, została uregulowana nieogłoszonym publicznie aktem prawa wewnętrznie obowiązującego, opracowanym przez organ administracji rządowej. W delegacji do wydania rozporządzenia zawartej w art. 9 ustawy o systemie powiadamiania ratunkowego jako wytyczną odnośnie do jego treści wskazano zapewnienie sprawnej obsługi zgłoszeń alarmowych ${ }^{19}$.

Opisany sposób systemu działania eCall pozwala zauważyć, że dotychczasowe orzecznictwo ETPCz nie jest adekwatne do informacji

19 Art. 9 ustawy o systemie powiadamiania ratunkowego: „Minister właściwy do spraw administracji publicznej określi, w drodze rozporządzenia:

1) organizację centrów oraz kryteria tworzenia oddziałów centrum, o których mowa w art. 6 ust. 3 ,

2) sposób funkcjonowania centrów oraz realizacji zadań przez centra,

3) ogólne procedury obsługi zgłoszeń alarmowych oraz sposób opracowywania i aktualizacji szczegółowych procedur,

4) ogólne procedury obsługi zgłoszeń alarmowych w przypadku, o którym mowa w art. 8 ust. 2, oraz sposób opracowywania i aktualizacji szczegółowych procedur,

5) maksymalną liczbę operatorów numerów alarmowych i sposób jej podziału na poszczególne centra

- uwzględniając konieczność zapewnienia sprawnej obsługi zgłoszeń alarmowych". 
uzyskiwanych za jego pośrednictwem, choć może dostarczyć istotnych wskazówek interpretacyjnych. Stanowisko Trybunału jest tożsame z wyrażonym przez Sąd Najwyższy w tym zakresie, że prawo do nieobciążania samego siebie przysługuje również osobie podejrzanej, przy czym nie jest ono uzależnione od prowadzenia $\mathrm{w}$ tej sprawie postępowania karnego. ETPCz podkreśla, że dla realizacji tego uprawnienia wymagane jest, by oskarżyciel był w stanie udowodnić winę oskarżonego bez odwoływania się do dowodów uzyskanych w wyniku podstępu lub przymusu stosowanych wbrew jego woli ${ }^{20}$. Wskazuje się, że ten ostatni może mieć charakter faktyczny lub prawny, istotą zasady nemo se ipsum accusare tenetur bowiem jest wolność wyboru oskarżonego co do kształtowania przez niego kontaktów z organami ścigania ${ }^{21}$. Norma ta może być prawidłowo realizowana tylko wtedy, gdy jest on w pełni świadomy przysługujących mu praw i w takiej sytuacji przekazuje władzom określone informacje o przestępstwie, którego popełnienie mu się zarzuca ${ }^{22}$. Trybunał uznał także, że dla realizacji omawianej zasady niezbędne jest istnienie gwarancji proceduralnych niewykorzystania $\mathrm{w}$ postępowaniu karnym prowadzonym przeciwko oskarżonemu informacji przez niego przekazanych ${ }^{23}$. Co do dowodów rzeczowych uzyskanych od oskarżonego pod przymusem, ale istniejących niezależnie od jego woli, np. dokumentów zatrzymanych w trakcie przeszukania, próbki wydychanego powietrza, krwi czy DNA, Trybunał stwierdził, że nie są one objęte prawem do nieobciążania się. Nie dotyczy to jednak wszelkich dowodów rzeczowych, zasada nemo se ipsum accusare tenetur znajduje bowiem zastosowanie w sytuacji, gdy nie zostaną one ujawnione przez organy ścigania, ale $\mathrm{w}$ wyniku zobowiązania potencjalnego oskarżonego do ich dostarczenia ${ }^{24}$.

20 Wyrok ETPCz z dnia 17 grudnia 1996 r. w sprawie Saunders przeciwko Zjednoczonemu Królestwu, skarga nr 19187/91, § 68.

${ }^{21}$ Należy jednak zauważyć, że w jednym ze swoich orzeczeń trybunał wskazał, że groźba grzywny, wymierzanej potencjalnemu oskarżonemu w przypadku odmowy złożenia przysięgi zeznawania prawdy, nie jest niedozwolonym sposobem wpłynięcia na jego decyzję przekazania określonych informacji organom ścigania. Por. wyrok ETPCz z dnia 20 października 1997 r. w sprawie Serves przeciwko Francji, skarga nr 20225/92, $\S 47$.

22 B. Sitkiewicz, Reguta nemo se ipsum accusare tenetur. Glosa do wyroku ETPC z dnia 18 lutego 2010 r., 39660/02, Przegląd Sądowy 2012, nr 6, s. 139.

${ }^{23}$ W. Jasiński, Prawo do nieobcią̇ania się w procesie karnym w świetle standardów strasburskich, Prokuratura i Prawo 2015, nr 7-8, s. 24.

24 Tamże, s. 30-31. 
Nieadekwatność orzeczeń ETPCz dotyczących zasady nemo se ipsum accusare tenetur $\mathrm{w}$ odniesieniu do informacji pozyskanych $\mathrm{z}$ systemu eCall wynika z tego, że one wszystkie dotyczą sytuacji, w której w jakiś sposób dochodzi do przełamania woli oskarżonego lub wpłynięcia na nią, także w stosunku do znajdujących się w jego dyspozycji dowodów rzeczowych. Istota omawianego systemu powiadamiania ratunkowego polega natomiast na tym, że wysłanie zgłoszenia następuje niezależnie od woli i działania kierowcy pojazdów. W związku z tym wszelkie wskazane przez Trybunał kryteria mogą być stosowane tylko w pewnym stopniu, z uwzględnieniem tej kluczowej odmienności. Należy jednak zwrócić jeszcze uwagę na dwa orzeczenia - Weh przeciwko Austrii ${ }^{25}$ oraz Jalloh przeciwko Niemcom ${ }^{26}$ - które zostaną wykorzystane w dalszej analizie problemu. W pierwszym z nich przyjęto, że podanie danych kierującego pojazdem nie jest jeszcze samo w sobie inkryminujące, a więc ustanowienie sankcji grzywny za odmowę udzielenia takiej informacji nie narusza zasady nemo se ipsum accusare tenetur. W drugim $\mathrm{z}$ nich stwierdzono natomiast, że jednym $\mathrm{z}$ argumentów przemawiających za uznaniem podania środków wymiotnych za naruszeniem tej zasady było zastosowanie tej drastycznej metody w stosunku do sprawcy przestępstwa o niewielkim ciężarze gatunkowym, co faktycznie oznacza, że Trybunał dokonał ważenia zasady prawa do nieobciążania się i ochrony interesu publicznego.

We wskazanych przepisach polskiego rozporządzenia w sprawie organizacji i funkcjonowania centrów powiadamiania ratunkowego nie odwołano się wprost do potrzeby zapewnienia efektywnego uzyskania pomocy przez osoby jej potrzebujące, jednak wspomniana sprawność działania centrów powiadamiana ratunkowego powinna być właśnie na to nakierowana. Bardziej dosłownie wartości stojące za wprowadzonymi rozwiązaniami normatywnymi wyrażono w przywołanym we wstępie w punkcie (7) preambuły rozporządzenia Parlamentu Europejskiego i Rady Unii Europejskiej. Wskazano w nim, że wprowadzenie obowiązku

25 Wyrok ETPCz z dnia 8 kwietnia 2004 r. w sprawie Weh przeciwko Austrii, skarga nr 38544/97. Trybunał stwierdził, że nie narusza prawa do nieobciążania się ciążący na właścicielu pojazdu obowiązek wskazania osoby, która nim kierowała w momencie popełnienia wykroczenia zarejestrowanego przez radar.

26 Wyrok ETPCz z dnia 11 lipca 2006 r. w sprawie Jalloh przeciwko Niemcom, skarga nr 54810/00. Trybunał uznał, że naruszeniem omawianej zasady było podanie osobie podejrzanej o handel narkotykami środków wymiotnych, dzięki czemu wydaliła ona z organizmu połknięty wcześniej woreczek z kokainą. 
montowania systemu eCall motywowane było potrzebą sprawniejszego informowania służb ratowniczych o wypadkach drogowych i zmniejszenia liczby ofiar śmiertelnych i ciężko rannych. W związku z tak jasno wyrażonymi motywami unijnego prawodawcy, przy próbach dokonania trafnej interpretacji prawa do nieobciążania się w zakresie informacji wysyłanych przez system eCall można odwołać się do wykładni regulacji cechujących się zbliżonym ratio legis. W aktualnie obowiązującej polskiej procedurze karnej normę o zbliżonym celu wyrażono w art. 199 K.p.k ${ }^{27}$. Jak trafnie wskazuje się w orzecznictwie i doktrynie, zakaz dowodowy ustanowiony $\mathrm{w}$ tym przepisie ${ }^{28}$ "sprowadza się do niedopuszczalności wykorzystywania jako dowodu oświadczeń oskarżonego złożonych w warunkach specyficznych, wobec szczególnego rodzaju osób, w sytuacjach, w których szczerość staje się naturalną koniecznością" ${ }^{29}$, a „celem tego zakazu w zakresie dotyczącym lekarza jest ochrona zaufania konkretnego oskarżonego, korzystającego z pomocy lekarskiej, do osób udzielających mu takiej pomocy"30. Podkreśla się także, że „zakaz dowodowy uregulowany w art. 199 K.p.k. obejmuje wszelkie oświadczenia oskarżonego dotyczące zarzucanego mu czynu" ${ }^{31}$. Z perspektywy analizowanego problemu istotne jest również, że „oświadczenie złożone wobec lekarza nie może stanowić dowodu także wówczas, gdy złożone zostało przed formalnym postawieniem sprawcy w stan podejrzenia"32. Zakaz dowodowy z art. 199 K.p.k. został w Polsce po raz pierwszy ustanowiony w K.p.k. z 1997 r., we wcześniejszych kodyfikacjach rozwiązanie takie nie funkcjonowało. Wprowadzenie tej normy było reakcją ustawodawcy na orzecznictwo Sądu Najwyższego dopuszczające przeprowadzanie dowodów

27 Art. 199 K.p.k.: „Złożone wobec biegłego albo wobec lekarza udzielającego pomocy medycznej oświadczenia oskarżonego, dotyczące zarzucanego mu czynu, nie mogą stanowić dowodu".

${ }^{28} \mathrm{~W}$ istocie $\mathrm{w}$ przepisie tym ustanowiono dwa zakazy dowodowe - jeden dotyczący oświadczeń złożonych wobec biegłego, drugi złożonych wobec lekarza udzielającego pomocy medycznej. W związku z tematem artykułu ograniczę się wyłącznie do analizy drugiego z tych zakazów.

29 Wyrok SA w Lublinie z dnia 21 sierpnia 2012 r., sygn. akt II AKa 173/12.

30 R. Stefański, S. Zabłocki (red.), Komentarz do art. 199 k.p.k., w: Kodeks postępowania karnego, t. 2: Komentarz do art. 167-296, Warszawa 2019, s. 525.

31 Postanowienie SN z dnia 28 czerwca 2012 r., sygn. akt III KK 366/11.

32 Wyrok SN z dnia 24 stycznia 2008 r., sygn. akt V KK 230/07. 
z oświadczeń oskarżonego co do zarzucanego mu czynu złożonych wobec lekarza udzielającego mu pomocy albo wobec biegłego ${ }^{33}$.

Podczas interpretacji art. 199 K.p.k. pojawić się mogą wątpliwości co do zakresu podmiotowego tego przepisu. Na aprobatę zasługuje stanowisko, zgodnie z którym art. 199 Kp.k. dotyczy wszystkich osób posiadających tytuł lekarza, niezależnie od posiadania przez nich uprawnień do wykonywania zawodu. Jedynym ograniczeniem ustanowionym w art. 199 K.p.k. jest udzielanie pomocy medycznej. Znaczenie ma bowiem okoliczność, czy dana osoba posiada wiedzę medyczną w zakresie wystarczającym do udzielenia takiej pomocy ${ }^{34}$. W doktrynie pojawiły się również wątpliwości co do sytuacji, w której potencjalny oskarżony kieruje co prawda swoje oświadczenie do lekarza udzielającego mu pomocy medycznej, ale słyszą je również inne osoby. Dla omawianego zagadnienia istotny jest przypadek zobrazowany sytuacją, w której poszkodowany, a jednocześnie sprawca wypadku, leży na poboczu drogi i udziela lekarzowi w ramach wywiadu medycznego informacji dotyczących zdarzenia, będących jednocześnie informacjami dotyczącymi czynu, którego popełnienie zostanie mu zarzucone. Przy tym oświadczenia te słyszą inne osoby obecne na miejscu akcji ratowniczej, np. ratownicy, strażacy, funkcjonariusze Policji i inni świadkowie, a poszkodowany nie ma żadnego wpływu na ich obecność przy rozmowie. W takiej sytuacji przyjmuje się, że zakazem dowodowym z art. 199 K.p.k. objęte jest również przesłuchanie tych osób na okoliczność oświadczeń złożonych wobec lekarza. Uzasadnia się to ochroną szczerości przyszłego podejrzanego, niezbędnej dla efektywnego udzielenia mu pomocy medycznej, a przy tym zakaz z art. 199 K.p.k. nie dotyczy przesłuchania konkretnej osoby, ale uzyskania konkretnych informacji ${ }^{35}$.

Skoro wartością chronioną przez art. 199 K.p.k. jest zdrowie lub życie ludzkie, to można by oczekiwać, że pozycja analogiczna do lekarza zostanie przyznana przedstawicielom innych zawodów ratujących te najistotniejsze dobra. W związku z tym zdziwienie musi budzić argumentacja Sądu Apelacyjnego w Gdańsku:

33 R. Stefański, S. Zabłocki, Komentarz do art. 199 k.p.k..., s. 523, wraz z przywołanym w punkcie 4. orzecznictwem.

34 M.J. Urbaniak, Zakres obowiązywania zakazu dowodowego przewidzianego wart. 199 k.p.k, Prokuratura i Prawo 2012, nr 7-8, s. 127-132.

35 Tamże, s. 134-135. 
Zarówno w doktrynie, jak i w judykaturze ugruntowany jest pogląd, że przepis ten obejmuje zakazem dowodowym wszelkie oświadczenia oskarżonego składane wobec lekarza udzielającego właśnie jemu pomocy medycznej, dotyczące zarzucanego mu czynu, niezależnie od ich treści. [...] W realiach rozpoznawanej sprawy z taką sytuacją nie mamy w ogóle do czynienia. Przypomnieć należy, że na polecenie dyspozytorki pogotowia ratunkowego do miejscowości J. gm. W. karetką pogotowia udał się zespół medyczny w skład którego nie wchodził lekarz medycyny tylko ratownicy medyczni, którzy próbowali udzielić pomocy pokrzywdzonemu. Dopiero po stwierdzeniu jego śmierci został wezwany lekarz pogotowia, który wystawił kartę zgonu R. S. Skoro zatem ratownicy medyczni (nie będący lekarzami) nie udzielali pomocy medycznej oskarżonej (poza iniekcją leku uspakajającego) nie było żadnych przeszkód do przesłuchania ich w charakterze świadków na okoliczność przebiegu przeprowadzonej interwencji ${ }^{36}$.

Współcześnie osobami udzielającymi pomocy jako pierwsze są często właśnie ratownicy, nieraz działający pod nieobecność lekarza, jak choćby w stanie faktycznym opisanym w przytoczonym orzeczeniu. Można sobie jednak bez problemu wyobrazić sytuację, w której nieudzielenie ratownikom informacji może skutkować zagrożeniem zdrowia lub życia, np. gdy sprawca przestępstwa pobicia nie informuje przybyłych na miejsce zdarzenia ratowników o obrażeniach zadanych mu ostrym narzędziem przez broniącego się przed nim pokrzywdzonego, w celu oddalenia od siebie ewentualnych podejrzeń. W takiej sytuacji podejrzany może nie mieć możliwości oświadczyć akurat lekarzowi, jakich obrażeń doznał i w jakich okolicznościach, w czasie pozwalającym na uniknięcie niebezpieczeństwa dla jego zdrowia lub życia. Może prowadzić to do sytuacji, w której wartości chronione przez art. 199 K.p.k. będą zagrożone, podczas gdy dałoby się temu zapobiec przez analogiczne stosowanie tego przepisu do ratowników medycznych w drodze wykładni funkcjonalnej. Analogia ta jest o tyle uzasadniona, że za taką interpretacją przemawia wprost ratio legis tego zakazu dowodowego. Jakkolwiek przyjmuje się, że w polskim procesie karnym zasadą jest swoboda dowodzenia, a zakazy dowodowe, jako wyjątki od niej, należy interpretować zwężająco, to jednak przyjmuje się, chociaż niejednomyślnie, że gdyby w dążeniu do ustalenia prawdy miało dojść do naruszenia podstawowych praw jednostki, zwłaszcza tych przysługujących podejrzanemu, to zasadna jest interpretacja rozszerzająca zakazów

36 Wyrok SA w Gdańsku z dnia 15 maja 2013 r., sygn. II AKa 130/13. 
dowodowych ${ }^{37}$. Skoro troska o życie i zdrowie osoby, której udzielana jest pomoc, przemawia za tym, by informacje przekazane lekarzowi objąć zakazem dowodowym, to tak samo powinny one uzasadniać rozciągnięcie zakresu tej normy na ratowników medycznych ${ }^{38}$. Oczywiście w tej kwestii pożądana byłaby ingerencja ustawodawcy, jednak już sama wykładnia obowiązujących przepisów czyni ten wniosek uzasadnionym.

Uwagi poczynione na temat sytuacji procesowej ratowników medycznych są aktualne również $\mathrm{w}$ stosunku do informacji uzyskanych za pośrednictwem systemu pokładowego eCall. Jak wyraźnie wskazano w preambule do rozporządzenia nakładającego obowiązek wyposażania weń nowych samochodów, celem wdrożenia tego rozwiązania jest m.in. „zmniejszenie liczby ofiar śmiertelnych i osób ciężko rannych”. Preambuły aktów prawa unijnego służą wyrażeniu intencji, jakimi kierował się europejski prawodawca, wprowadzając określone rozwiązania. Z tego powodu mają one istotne znaczenie normatywne, wykorzystywane w procesie interpretacji poszczególnych aktów prawnych. Błędem byłoby więc dokonywanie wykładni prowadzącej do sprzeczności z wartościami wyrażonymi wprost w preambule. W związku z tym należy przyjąć, że wysyłanie przez system eCall informacji do właściwych służb ma służyć

37 Z. Kwiatkowski, Zakazy dowodowe w procesie karnym, Zakamycze 2005, s. 62 wraz z przywołanym tam przeciwnym poglądem.

38 W literaturze analogiczny pogląd został wyrażony w odniesieniu do pielęgniarek, R. Stefański, S. Zabłocki, Komentarz do art. 199 k.p.k..., s. 524-525. Przywołano tam wyrok SA w Katowicach z dnia 21 października 2013 r., sygn. II AKa 334/13: „Zakaz dowodowy winien obejmować także wszelkie oświadczenia składane pielęgniarkom w trakcie udzielania przez nie pomocy medycznej oskarżonemu, bądź podejrzanemu, a nawet osobie, która jeszcze takiego statusu w procesie nie uzyskała. Częste są bowiem w praktyce przypadki, że zespół karetki pogotowia ratunkowego udaje się na miejsce zdarzenia w składzie pozbawionym lekarza. Wówczas to między innymi pielęgniarka, co wynika wprost z ustawy o zawodzie pielęgniarki i położnej, zobowiązana jest do sporządzenia stosownej dokumentacji i samodzielnego udzielania w określonym zakresie świadczeń zapobiegawczych, diagnostycznych, leczniczych i rehabilitacyjnych oraz medycznych czynności ratunkowych. Możliwość przesłuchania pielęgniarki na okoliczność złożonych przez oskarżonego oświadczeń dotyczących zarzucanego mu czynu, stanowiłaby bez wątpienia obejście bezwzględnego zakazu dowodowego przewidzianego w art. 199 K.p.k., choć dotyczy on wyłącznie lekarzy i biegłych. Za niedopuszczalne uznać należało przesłuchanie pielęgniarki na okoliczności związane z oświadczeniami, jakie złożyła jej oskarżona w trakcie udzielania pomocy medycznej, ale wyłącznie w zakresie podawanych przez oskarżoną faktów dotyczących zarzucanego jej czynu. Świadek mogła być przesłuchiwana na okoliczności niezwiązane z zarzutem, jaki w czasie późniejszym postawiono oskarżonej”. 
ochronie życia lub zdrowia osób korzystających z samochodu. Cele te są więc tożsame z wartościami chronionymi przez art. 199 K.p.k. Wykorzystanie systemu eCall cechują jednak istotne odmienności w stosunku do sytuacji objętych zakresem normowania tego przepisu, nawet gdyby przyjąć w drodze wykładni rozszerzającej jego zastosowanie w stosunku do ratowników medycznych. Przede wszystkim nie dochodzi tu do złożenia jakiegokolwiek oświadczenia co do czynu, którego popełnienie można by potencjalnie zarzucić. Zgłoszenie dokonane przez system eCall można by pod tym względem porównać do wykonania telefonu na numer alarmowy przez sprawcę zdarzenia drogowego. Tego rodzaju informacja o samym zaistnieniu sytuacji wymagającej interwencji służb ratowniczych nie jest więc objęta zakazem dowodowym z art. 199 K.p.k. Za takie można by dopiero uznać wiadomości podane przez sprawcę zdarzenia personelowi medycznemu po jego przybyciu na miejsce.

Moim zdaniem samo to stwierdzenie nie przesądza jeszcze legalności wykorzystania przez organy ścigania informacji uzyskanej za pośrednictwem systemu eCall. Istotną odmiennością względem wykonania telefonu na numer alarmowy przez sprawcę zdarzenia drogowego jest to, że takie działanie wynika z aktywności podjętej przez samego potencjalnego oskarżonego. Skutek tej czynności, w postaci zjawienia się na miejscu odpowiednich służb, jest na tyle przewidywalny, że nie są konieczne jakiekolwiek pouczenia o takich konsekwencjach powiadomienia o zdarzeniu. Skoro więc sprawca decyduje się na takie działanie, obojętnie z jakich pobudek, to sam godzi się na to, że organy państwa powezmą informację o spowodowanym przez niego zdarzeniu drogowym. Pod względem stosunku woli potencjalnego oskarżonego do przekazania informacji o popełnionym przez niego czynie system eCall wykazuje natomiast podobieństwa do wszelkich innych urządzeń gromadzących na co dzień informacje o ludzkich działaniach, np. kamer monitoringu, stacji BTS, systemu monitorowania ruchu na drogach publicznych. Wszystkie te systemy gromadzą najróżniejsze dane, które mogą być i w praktyce są wykorzystywane na potrzeby postępowania karnego, także jeśli są one zbierane dzięki korzystaniu przez oskarżonego z należących do niego przedmiotów, np. telefonu komórkowego czy samochodu. Należy jednak zwrócić uwagę, że żaden z tych systemów, z wyjątkiem niektórych monitoringów wizyjnych miast, nie jest bezpośrednio nakierowany na bieżące automatyczne przekazywanie służbom informacji o zdarzeniach mogących stanowić realizację czynów zabronionych lub ich okolicznościach, jak ma 
to miejsce $\mathrm{w}$ przypadku systemu eCall. Ponadto urządzenia monitoringu i monitorowania ruchu na drogach utrwalają zachowania potencjalnych oskarżonych bez żadnego współdziałania z ich strony. Inaczej sytuacja wygląda w przypadku stacji BTS, $\mathrm{z}$ ich pomocą bowiem dokonywana jest transmisja danych z telefonu takiej osoby. Należy jednak zwrócić uwagę, że głównym celem przyświecającym rozwojowi infrastruktury telekomunikacyjnej nie jest umożliwienie sprawnego udzielenia pomocy użytkownikom telefonów komórkowych, jak ma to miejsce odpowiednio w stosunku do samochodów wyposażonych w system eCall. W związku z tym wykorzystywanie informacji pochodzących ze stacji BTS wydaje się niekontrowersyjne $\mathrm{w}$ kontekście prawa do nieobciążania się. Odnosząc się zaś jeszcze do sytuacji związanej z monitoringiem, należy zwrócić uwagę, że może dojść do sytuacji, w której dowodem przestępstwa będzie nagranie z kamery używanej wyłącznie przez jego sprawcę. Należy jednak zauważyć, że zasadniczo ma on możliwość bezkarnego zniszczenia takiego dowodu ${ }^{39}$, a w przypadku systemu eCall nie może nawet zdecydować o tym, kiedy jest on aktywny ${ }^{40}$.

Należy wreszcie zauważyć, że system eCall nie przekazuje wiadomości dotyczących okoliczności samego zdarzenia, a jedynie informację o jego zaistnieniu. Można więc twierdzić, że sama w sobie jest ona neutralna i nie

39 Jak trafnie wskazał SN w wyroku z dnia 5 sierpnia 2009 r., sygn. II KK 136/09, tzw. autopoplecznictwo, czyli utrudnianie postępowania karnego przez sprawcę objętego nim przestępstwa, nie realizuje znamion przestępstwa z art. 239 § 1 k.k. Pozostając w tematyce przestępstw przeciwko bezpieczeństwu w komunikacji, można więc wyobrazić sobie sytuację, w której sprawca wypadku kasuje nagrania z zamontowanego w swoim samochodzie wideorejestratora i nie ponosi żadnych negatywnych konsekwencji prawnych swojego działania.

40 Przykłady można by mnożyć i objąć nimi choćby filmy i zdjęcia zrobione telefonem, z którego korzystał podejrzany, ale ujawnione w toku czynności procesowych. Należy podkreślić, że również w takiej sytuacji nie dochodzi do automatycznego przekazania tych informacji organom procesowym, ale do ich dobrowolnego wydania lub przymusowego odebrania na podstawie przepisów o zatrzymaniu rzeczy i przeszukaniu. Jeśli podejrzany nie zniszczy tych dowodów, to ponosi swoiste ryzyko utrwalenia śladów związanych z popełnieniem przez niego czynu zabronionego i przechowywania ich. Wymagana jest przy tym inicjatywa organów procesowych nakierowana na zdobycie dowodów, podczas gdy system eCall automatycznie przekazuje informacje o zdarzeniu drogowym do centrum powiadamiania ratunkowego, które może powiadomić policję. Ponadto brak jest obecnie jakichkolwiek regulacji dotyczących dopuszczalności wykorzystania otrzymanego $\mathrm{w}$ ten sposób dowodu, w przeciwieństwie do kwestii przeszukania i zatrzymania rzeczy. 
dostarcza żadnych dowodów obciążających sprawcę. Uważam, że ujmując problem z tej perspektywy, wykazuje on istotne podobieństwo z zagadnieniem rozstrzygniętym przez ETPC z w sprawie Weh przeciwko Austrii. W wydanym wówczas orzeczeniu Trybunał stwierdził, że nałożenie na właściciela pojazdu obowiązku wskazania kierującego pojazdem, który popełnił wykroczenie, nie narusza zasady nemo se ipsum accusare tenetur. Uznał bowiem, że związek między podaniem danych osoby prowadzącej pojazd a potencjalnym postępowaniem karnym przeciwko niej jest daleki i hipotetyczny. Orzeczenie to zapadło większością głosów cztery do trzech, a w zdaniach odrębnych przegłosowanych sędziów wskazano, że ujawnienie danych kierującego pojazdem i przyszłe postępowanie wykroczeniowe są ze sobą ściśle związane. Ponadto stwierdzono, że w rzeczywistości dochodzi tu do sytuacji, w której stawia się niewątpliwy interes społeczny w ściganiu sprawców przestępstw drogowych ponad prawem jednostki do nieobciążania się ${ }^{41}$. Podzielam stanowisko wyrażone w opisanych zdaniach odrębnych. Co więcej, uważam, że uzasadnienie orzeczenia Trybunału można uznać za wątpliwe ${ }^{42}$, we wcześniejszych judykatach bowiem konsekwentnie przyjmowano, że brak obowiązku dostarczania dowodów przeciwko samemu sobie występuje niezależnie od faktu formalnego prowadzenia postępowania karnego. Natomiast w sprawie Jalloh przeciwko Niemcom ETPCz stwierdził wprost, że naruszenie zasady nemo se ipsum accusare tenetur wynikało $\mathrm{z}$ tego, że zastosowano środki nieproporcjonalne do wagi przestępstwa, o którego popełnienie podejrzewanego skarżącego. Tym samym przyjął, że można rozważać odstąpienie od prawa do nieobciążania siebie, jeśli jest to uzasadnione interesem publicznym ${ }^{43}$.

Uważam, że poczynione wyżej spostrzeżenia są adekwatne w stosunku do zgłoszeń przekazywanych z wykorzystaniem systemu eCall. Nie można zaprzeczyć, że są one wyłącznie neutralnymi informacjami o zaistnieniu zdarzenia drogowego. Według mnie należy jednak przyjąć, że ich uzyskanie przez organy ścigania jest ściśle związane z późniejszym

${ }^{41}$ W. Jasiński, Prawo do nieobciążania..., s. 20.

${ }^{42}$ W. Jasiński, Prawo do nieobciążania się a interes publiczny w sprawach karnych (w orzecznictwie Europejskiego Trybunału Praw Człowieka), Państwo i Prawo 2015, z. 11, s. 90. Wskazano tu również orzeczenie w podobnej sprawie - O’Halloran and Francis v. Zjednoczone Królestwom wyrok ETPCz z dnia 29 czerwca 2007 roku, skargi nr 15809/02, 25624/02. W wyroku tym uzasadniono obowiązek wskazania sprawcy wykroczenia szczególnym reżimem, któremu poddani są właściciele pojazdów.

43 Tamże, s. 84-87. 
prowadzeniem postępowania karnego, jeśli takie zdarzenie zostanie zakwalifikowane jako czyn zabroniony ${ }^{44}$. W związku z tym takie informacje, mimo tego, że same w sobie mają neutralny charakter, powinny być objęte zakresem zakazu nemo se ipsum accusare tenetur, a przeciwny wniosek można co prawda uzasadnić interesem publicznym, jednak może to prowadzić do argumentu z równi pochyłej, wtedy bowiem w każdej sprawie będzie można dokonać podobnego ważenia między tymi wartościami. Nie sposób jednak zaprzeczyć, że do uzyskania właściwych dowodów winy konkretnej osoby prowadzi nie samo zgłoszenie dokonane przez system eCall, ale czynności podjęte w związku z nim przez organy ścigania. $W$ polskiej procedurze karnej formalnie nie obowiązuje zakaz wykorzystania "owoców zatrutego drzewa”, w związku z czym nie sposób samoistnie uznać za nielegalne dowody uzyskane w następstwie czynności podjętych po powzięciu informacji uzyskanej w sposób bezprawny ${ }^{45}$.

W związku z powyższymi twierdzeniami uważam, że informacje uzyskiwane za pośrednictwem systemu pokładowego eCall powinny być objęte zakazem wykorzystania ich ze względu na zasadę nemo se ipsum accusare tenetur. Jakkolwiek cele wprowadzenia tej technologii, wyrażone wprost przez unijnego prawodawcę, są zbieżne z wartościami chronionymi przez art. 199 K.p.k., to przepis ten nie może być normatywną podstawą dyskwalifikacji tego rodzaju dowodów, w tej sytuacji bowiem nie dochodzi do złożenia jakiegokolwiek oświadczenia przez potencjonalnego

${ }^{44}$ Warto przy tym odnotować stanowisko wyrażone przez SN w wyroku z dnia 28 czerwca 2001 r., sygn. II KKN 412/98, zgodnie z którym „«wywiad» o okolicznościach wypadku, którego kierowca motocykla udzielił funkcjonariuszowi policji w chwili, gdy nie podjęto jeszcze przeciwko niemu jakichkolwiek czynności procesowych, to zgodnie z zasadą nemo se ipsum accusare tenetur niedopuszczalne było późniejsze dokonanie czynności procesowych o charakterze dowodowym w postaci sporządzenia zeznań tegoż funkcjonariusza określających treść «wywiadu»". Rzecz jasna pogląd ten dotyczy oświadczeń o przebiegu zdarzenia, a nie samej informacji o jego zaistnieniu, należy jednak zauważyć, że tego rodzaju „,wywiad”, uznawany za niedopuszczalny z uwagi na normę nemo se ipsum accusare tenetur, jest - zarówno z perspektywy czasowej, jak i gwarancji procesowych przysługujących oskarżonemu - najbliższy przekazaniu samej wiadomości o konkretnym zdarzeniu.

45 Wniosek ten jest uzasadniony tym, że od 15 kwietnia 2016 r. art. 168a K.p.k. stanowi, że dowodu nie można uznać za niedopuszczalny wyłącznie na tej podstawie, że został uzyskany z naruszeniem przepisów postępowania. Poglądu tego moim zdaniem nie falsyfikuje głośny precedensowy wyrok SA we Wrocławiu z dnia 27 kwietnia 2017 r., sygn. II AKa 213/16. 
podejrzanego. Na tym właśnie polega istota tego rozwiązania, że informacja przekazywana jest niezależnie od jego woli, a więc może nastąpić nawet wbrew jego życzeniu. Mechanizm ten działa natomiast w oparciu o system zainstalowany $\mathrm{w}$ samochodzie, z którego osoba ta korzysta. Uważam, że bezprawność wykorzystania informacji pochodzącej z systemu eCall wynika z art. $74 \S 1$ K.p.k. i wyrażonej w nim reguły nemo se ipsum accusare tenetur. Wniosek ten pośrednio wspierają wskazania ETPCz, który stwierdził, że norma ta nakazuje, by informacje pochodzące od osoby potencjalnie podejrzanej były przekazywane przez nią organom ścigania w pełni dobrowolnie. Nie uznaje przy tym za trafne orzeczenia w sprawie Wen przeciwko Austrii, gdyż sądzę, że stan faktyczny oceniany w tym wyroku cechują istotne podobieństwa do uzyskiwania informacji z systemu eCall.

Należy ponadto podkreślić, że wadliwość tego rodzaju dowodu dotyczyłaby wyłącznie określonego środka dowodowego, nie zaś dowodzenia samej okoliczności, co wynika z nieobowiązywania $\mathrm{w}$ europejskim porządku prawnym doktryny "owoców zatrutego drzewa”. Za bezprawne należałoby więc uznać wyłącznie skorzystanie z informacji o zdarzeniu drogowym pochodzącym z systemu eCall zamontowanym w pojeździe sprawcy, co jednak nie oznacza, że organ procesowy w ogóle nie mógłby prowadzić czynności procesowych w sprawie zdarzenia, które doprowadziło do przekazania wiadomości przez tenże system. Ponadto za w pełni prawidłową uznaję ewentualną aktywność organów procesowych w sytuacji, gdy informacje o zdarzeniu pochodziłyby także z innego źródła, np. od świadka wzywającego policję lub pogotowie, systemu eCall z pojazdu kierowanego przez innego niż sprawca uczestnika zdarzenia, a nawet od samego sprawcy, jeśli tylko przekazałby on informacje o zdarzeniu z własnej inicjatywy. Pierwszy z przytoczonych przykładów jest oczywisty i obejmuje sytuacje, w których świadek, w tym pokrzywdzony, zawiadamia, najczęściej telefonicznie, o zdarzeniu, które zauważył. Drugi z przykładów obrazuje, że niedopuszczalność dowodu nie wynika wyłącznie z samego sposobu działania systemu eCall. Problem jego dopuszczalności pojawia się dopiero w sytuacji, gdy automatyczny sposób zgłaszania zdarzeń drogowych działa na niekorzyść osoby, do której dyspozycji został on oddany. Uznaje się bowiem, że przedmioty powinny służyć osobom, do których należą. Trudno więc zaakceptować sytuację, w której sam sprawca nie ma obowiązku zawiadamiania o popełnionym przez siebie przestępstwie, za to robi to system zainstalowany 
w należącym do niego pojeździe ${ }^{46}$. Z kolei ostatni z przywołanych przykładów - zawiadomienie o zdarzeniu pochodzące od samego sprawcy obrazuje, że o wadliwości dowodu nie decyduje jego przekazanie przez sprawcę zdarzenia, ale fakt, że w przypadku informacji z systemu eCall następuje ono bez jego woli.

Należy przy tym zauważyć, że jeśli przepisy nie ulegną zmianie, to z czasem wszystkie pojazdy zostaną wyposażone w system eCall. Może doprowadzić to do sytuacji, w której nikt nie będzie już zawiadamiać służb ratunkowych o wypadkach, tego rodzaju zgłoszenia bowiem będą przekazywane automatycznie. Opisany we wstępie kazus wyraźnie pokazuje, że już obecnie informacje pochodzące z systemu eCall mogą doprowadzić organy procesowe do uzyskania informacji, w posiadanie których nie weszłyby $\mathrm{w}$ inny sposób. W przywołanym stanie faktycznym, gdyby wiadomość o kolizji na parkingu podziemnym nie została przekazana automatycznie, to jej sprawca mógłby uniknąć odpowiedzialności za przestępstwo z art. 178a K.k., upływ czasu bowiem między zdarzeniem a ewentualnym badaniem kierowcy prawdopodobnie uniemożliwiłby wykazanie, że w momencie popełnienia czynu znajdował się on pod wpływem środka odurzającego. Skoro na sprawcy przestępstwa nie ciąży zaś obowiązek zawiadomienia o jego popełnieniu, co następnie uruchomiłoby łańcuch czynności procesowych ukierunkowanych na udowodnienie jego winy, to gromadzenie dowodów po otrzymaniu zgłoszenia z systemu eCall, jakkolwiek prawnie dopuszczalne, następuje dzięki uzyskaniu informacji w sposób sprzeczny z zasadą nemo se ipsum accusare tenetur. W związku z tym uzupełnieniem postawionej tezy jest postulat takiej nowelizacji procedury karnej, by wyjątkami ustanowionymi w art. 74 § 2 i 3 K.p.k. objąć również tego rodzaju informacje.

${ }^{46} \mathrm{~W}$ sytuacji, gdy jedyne wiadomości o zderzeniu pojazdów pochodziłyby z systemów eCall zainstalowanych w obu samochodach, a sprawcami byliby obaj kierujący, należałoby uznać, że dopuszczalny jest dowód z obu tych zgłoszeń, uznając, że w stosunku do każdego ze sprawców wiadomość o zdarzeniu pochodzi z drugiego pojazdu biorącego w nim udział. 


\section{Bibliografia}

Gronowska B., Wyrok Europejskiego Trybunatu Praw Człowieka z dnia 5 listopada 2002 r. w sprawie Allan przeciwko Zjednoczonemu Królestwu (dot. prawa oskarżonego do milczenia a wydobycia przyznania się do winy podstepem), Prokuratura i Prawo 2003, nr 6.

Haber J., Pojęcie i istota przesłanek procesu karnego, Państwo i Prawo 1967, z. 2.

Jasiński W., Prawo do nieobciążania się a interes publiczny w sprawach karnych (w orzecznictwie Europejskiego Trybunału Praw Człowieka), Państwo i Prawo 2015, z. 11.

Jasiński W., Prawo do nieobciążania się w procesie karnym w świetle standardów strasburskich, Prokuratura i Prawo 2015, nr 7-8.

Kwiatkowski Z., Zakazy dowodowe w procesie karnym, Zakamycze 2005.

Lach A., Granice badań oskarżonego w celach dowodowych. Studium w świetle reguty nemo se ipsum accusare tenetur i prawa do prywatności, Torun 2010.

Mazur P., Zmiana sytuacji procesowej osoby podejrzanej i oskarżonego a zasada prawdy materialnej po nowelizacji kodeksu karnego z dnia 10 stycznia 2003 r. (wybrane zagadnienia), w: Zasada prawdy materialnej, red. Z. Sobolewski, G. Artymiak, Zakamycze 2006

Numer alarmowy 112. Struktura, https:/ / www.gov.pl/web/numer-alarmowy-112/ struktura [dostęp: 27.11.2019 r.].

Rozmowa z Maciejem Pertyńskim, dziennikarzem motoryzacyjnym, https:/ / www. wirtualnemedia.pl/artykul/sportowy-mercedes-zawiadomil-policje-w-elblagu-o-tym-ze-uczestniczyl-w-wypadku-to-normalne-dzialanie-systemu-e-call-dlaczego-jak-korzystac [dostęp 19.11.2019 r.].

Sitkiewicz B., Reguła nemo se ipsum accusare tenetur. Glosa do wyroku ETPC $z$ dnia 18 lutego 2010 r., 39660/02, Przegląd Sądowy 2012, nr 6.

Sowiński P.K., Prawo oskarżonego do milczenia oraz reguła nemo se ipsum accusare tenetur na tle dążenia organów procesowych do poznania prawdy materialnej w procesie karnym, w: Zasada prawdy materialnej, Z. Sobolewski, G. Artymiak, Zakamycze 2006.

Stefański R., Zabłocki S. (red.), Komentarz do art. 199 k.p.k., w: Kodeks postepowania karnego, t. 2: Komentarz do art. 167-296, Warszawa 2019.

Urbaniak M.J., Zakres obowiazzywania zakazu dowodowego przewidzianego w art. 199 k.p.k., Prokuratura i Prawo 2012, nr 7-8.

\section{Streszczenie}

W artykule omówiono relację między rozwiązaniami prawnymi dotyczącymi systemu pokładowego eCall a zasadą nemo se ipsum accusare tenetur na przykładzie zdarzenia drogowego z sierpnia 2019 r. W pierwszej części opisano historię 
kształtowania się braku obowiązku autodenuncjacji oraz jego znaczenie w obecnie obowiązującym systemie prawa krajowego i europejskiego. W drugiej części omówiono sposób funkcjonowania systemu pokładowego eCall, w szczególności przyjmowania zgłoszeń przekazywanych za jego pomocą do służb ratowniczych. Zwracając uwagę na niespójność między przepisami dotyczącymi systemu eCall a zasadą nemo se ipsum accusare tenetur, poszukiwano drogi jej uniknięcia przez odwołanie się do zakazu dowodowego przesłuchania lekarza udzielającego pomocy medycznej podejrzanemu, wyrażonego w art. 199 K.p.k. oraz orzecznictwa Europejskiego Trybunału Praw Człowieka. W konkluzji przedstawiono argumenty przemawiające za tym, że w obecnym stanie prawnym wykorzystanie w procesie karnym informacji pochodzących z systemu eCall może stać w sprzeczności $\mathrm{z}$ brakiem obowiązku autodenuncjacji i wskazuję postulowane $\mathrm{w}$ tym zakresie zmiany ustawodawcze.

Słowa kluczowe: system pokładowy eCall, nemo se ipsum accusare tenetur, art. 199 K.p.k.

\section{VALIDITY OF THE NEMO SE IPSUM ACCUSARE TENETUR RULE ON THE BASE OF THE NEW TECHNICAL AND LEGAL SOLUTIONS IN AUTOMOTIVE INDUSTRY}

\section{Sum mary}

In this paper, I shall analyze the relation between eCall in-vehicle system legal regulations and the nemo se ipsum accusare tenetur rule on the basis of a car accident from August 2019. In the first part, I describe the historical development of this rule and its role in domestic and European legal systems. Secondly, I analyze how the eCall in-vehicle system works, especially the way in which the emergency services are notified about accidents. Stressing incoherence between regulations on the eCall in-vehicle system and the nemo se ipsum accusare tenetur rule, I'm looking for a solution for this problem by an analogy to the legal prohibition from article 199 of the Code of Criminal Procedure concerning the case of an intervening physician, who provides medical help to a suspect and the analysis of judgments of the European Court of Human Rights. In the conclusion, I argue that actually taking as evidence any information from an eCall in-vehicle system could be inconsistent with the nemo se ipsum accusare tenetur rule, so I suggest legal amendments to change this normative regulation.

Key words: eCall in-vehicle system, nemo se ipsum accusare tenetur, article 199 of the Code of Criminal Procedure 


\section{СФЕРА ПРИМЕНЕНИЯ ПРИНЦИПА NEMO SE IPSUM ACCUSARE TENETUR В СВЕТЕ НОВЫХ ТЕХНИЧЕСКИХ И ЮРИДИЧЕСКИХ РЕШЕНИЙ В АВТОМОБИЛЬНОМ ТРАНСПОРТЕ}

\section{Резюме}

В статье обсуждается взаимосвязь между правовыми решениями, касающимися европейской системы автоматического оповещения о дорожных происшествиях еCall и принципом пето se ipsum accusare tenetur на примере дорожного происшествия в августе 2019 года. В первой части описывается история формирования отсутствия обязательства заявлять в правоохранительные органы против себя и его значение в действующей системе национального и европейского права. Во второй части обсуждается порядок функционирования европейской системы eCall, в частности прием заявок, передаваемых с ее помощью в экстренные службы. Обращая внимание на противоречивость между положениями касающимися системы eCall и принципом пето se ipsum accusare tenetur, предпринята попытка найти способ избежать ее, ссылаясь на запрет на допрос врача, оказывающего медицинскую помощь подозреваемому на основании ст. 199 Уголовно-процессуального кодекса, а также судебной практики Европейского суда по правам человека. В заключение приводятся аргументы в пользу того, что в нынешнем правовом строе использование информации из системы еCall в уголовном процессе может вступать в противоречие с отсутствием обязанности заявлять против себя, а также указывается на предлагаемые законодательные изменения в этом отношении.

Ключевые слова: система eCall, nemo se ipsum accusare tenetur, статья 199 Уголовно-процессуального кодекса 